\title{
"There Is No Authority But Yourself": The Individual and the Collective in British Anarcho-Punk
}

\author{
RICH CROSS
}

\author{
You must learn to live with your own conscience, \\ your own morality, \\ your own decision, \\ your own self. \\ You alone can do it. \\ There is no authority but yourself \\ Crass \\ Yes Sir, I Will \\ 1983
}

\section{Introduction}

British anarchist punk band Crass's fifth studio album Yes Sir, I Will (released on the band's own label in 1983) was the most challenging and demanding record the group had yet committed to vinyl. ${ }^{1}$ Its tone was dark, the musical delivery harsh and disjointed, the political invective stark and unrelenting. The entire record seethed with anger, incredulity, and indignation. For the moment in which it was produced, Yes Sir, I Will was an entirely fitting testament to the position in which "anarcho-punk" now found itself. From its own origins in 1977, this dissident strand within British punk had connected with a new audience willing to take seriously the "revolutionary" cultural and political aspirations that punk rock had originally championed. Anarcho-punk concerned itself with urging the individual to prize themselves free of social conformity and the shackles of societal constraint, championing personal independence and the exercise of free will. At the same time, anarcho-punk declared, as an indivisible and parallel objective, its support for the liberation of the planet from the tyranny of the "war state" and the overthrow of the disfiguring and alienating capitalist system. These intertwined aims were pursued with both intense determination and unflagging self-belief. By 1983, however, the limitations and inadequacies of the new anarcho-punk movement had become as transparent as its evident strengths, even to the band that had served as the movement's principal catalyst. When it came to changing the world or to revolutionizing the lives of those attracted by its goals, anarcho-punk's reach continually appeared to exceed its grasp. Regardless of the political activity and artistic creativity the movement was able to inspire, for Crass and many of those around them it was never sufficient to realize the demands that it set for itself. And yet, in battling against their own political frustrations, the activists of anarcho-punk were scarcely alone.

The first Thatcher-led Conservative government elected in 1979 had presided over a sharp contraction in the British economy and had encountered stiff social and political opposition to its efforts to break with the post-War consensus. Its strict monetarist agenda required significant cuts in government spending and the withdrawal of state subsidies, which triggered a sharp rise in unemployment. The Thatcher administration also directed additional funding (as well as assigning additional powers) to the

${ }^{1}$ Crass, Yes Sir, I Will , Crass Records, 1983. 121984-2. 
police and law and order agencies. Internationally, Thatcher reaffirmed Britain's orientation as an active supporter of the United States's foreign policy, in the context of sharpening the Cold War standoff, which heralded the stationing of American nuclear missiles on UK soil. Many on the British political left had expected the electoral pendulum to swing against the Conservatives, but Britain's military victory in the Falklands-Malvinas War in 1982 saw a surge in support for the faltering government and paved the way for Thatcher's re-election in 1983 — on a strong state, pro-nuclear, anti-union platform.

There were waves of strikes across the public and private sectors, countless demonstrations against cuts in the social wage, rising job losses and the revival of the Nazi fringe, and to protest the expansion of state power. While the Campaign for Nuclear Disarmament (CND) mobilized and energized many hundreds of thousands of protestors, riots had convulsed inner-city communities as youth reacted against police harassment, endemic racism and worsening living conditions. The political atmosphere was one of overwhelming confrontation, polarization, and uncertainty.

The politics that underscored the work of these various opposition movements was a tangle of what were collectively (if inaccurately) deemed as "progressive" ideologies-from old-fashioned Labourism, Trotskyism and radical Leftism, to liberal anti-racism and ethical anti-militarism. At times, these disparate political strands could combine in temporary, if uneasy, alliances. At other moments, tensions between respectable and anti-establishment forces caused such coalitions to unravel. Anarchist politics-both innate and formal-had remained a significant, if incoherent, presence on the UK political fringe, particularly since the watershed of 1968 had accelerated British anarchism's post-War revival. ${ }^{2}$ Invigorated by the emergence of the "new left" (and the critique of the "reactionary" and "counter-revolutionary" leftist practice of the past that was central to its libertarian-left case), many currents within British anarchism also found their ideas refracted through the work of the emerging women's movement: particularly in its assertions that the "personal is political"; that disenfranchising organizational hierarchies needed to be subverted and undone; and that, in the arena of political action, ends and means were inseparable. As its influence grew, British anarchism remained conflicted by a matrix of tensions. While some activists labored within the anti-militarist and anti-nuclear movement, renouncing the utility of "physical force," others were animated by the appeal of covert paramilitarism (typified by the actions of the Angry Brigade). ${ }^{3}$ There were disagreements over questions of agency, strategy, and tactics; but libertarian politics (of numerous competing and complementary hues) came to provide a potent pole of attraction for those repelled by the traditional prescriptions of the left. However, by the tail end of the 1970s British anarchism's resurgence had faltered.

Perhaps surprisingly, it was punk rock that provided a key impetus for its revival, even if the punks who raised new anarchist banners of their own making were quickly revealed as in pursuit of very different goals. Ever since the Sex Pistols had embraced notoriety through the release of God Save the Queen and Anarchy in the UK, "anarchy" and "punk" had come to be seen as synonymous in mainstream public culture. For some, the connection emphasized only the vapidity and bogusness of punk; while others who saw punk's challenge as more significant, dismissed its ambitions as nihilistic and politically sterile. But by the time that the Pistols had imploded, a current had emerged from within punk that sought to make good on its original cultural and political promise- "anarcho-punk." Anarcho-punk identified itself as a "restorative," dissident movement within punk: one which aimed to reassert the primacy of punk as an agency of political subversion. Anarcho-punk lacked the strategic concerns, or the ideological and historical baggage of the formal anarchist movement, but it ignited the interest of tens of thousands of young punks with an anarchism visceral, passionate and angry, and through its insistence that punk rock itself might yet be refashioned into a revolutionary weapon. ${ }^{4}$

\footnotetext{
${ }^{2}$ See the discussion in Benjamin Franks, Rebel Alliances: The Means and Ends of Contemporary British Anarchism (Edinburgh: Oakland: AK Press, 2006).

${ }^{3}$ Gordon Carr, The Angry Brigade: The Cause and the Case (London: Victor Gollancz, 1975).

${ }^{4}$ See Penny Rimbaud's account of anarcho-punk's emergence in: Crass. A Series of Shock Slogans and Mindless Token Tantrums (London: Exitstencil Press, 1982). For an exploration of what the author sees as the innately subversive nature of authentic punk rock, which ranges over several decades, see Craig O'Hara, The Philosophy of Punk: More Than Noise (Edinburgh: San Francisco: AK Press, 1995).
} 


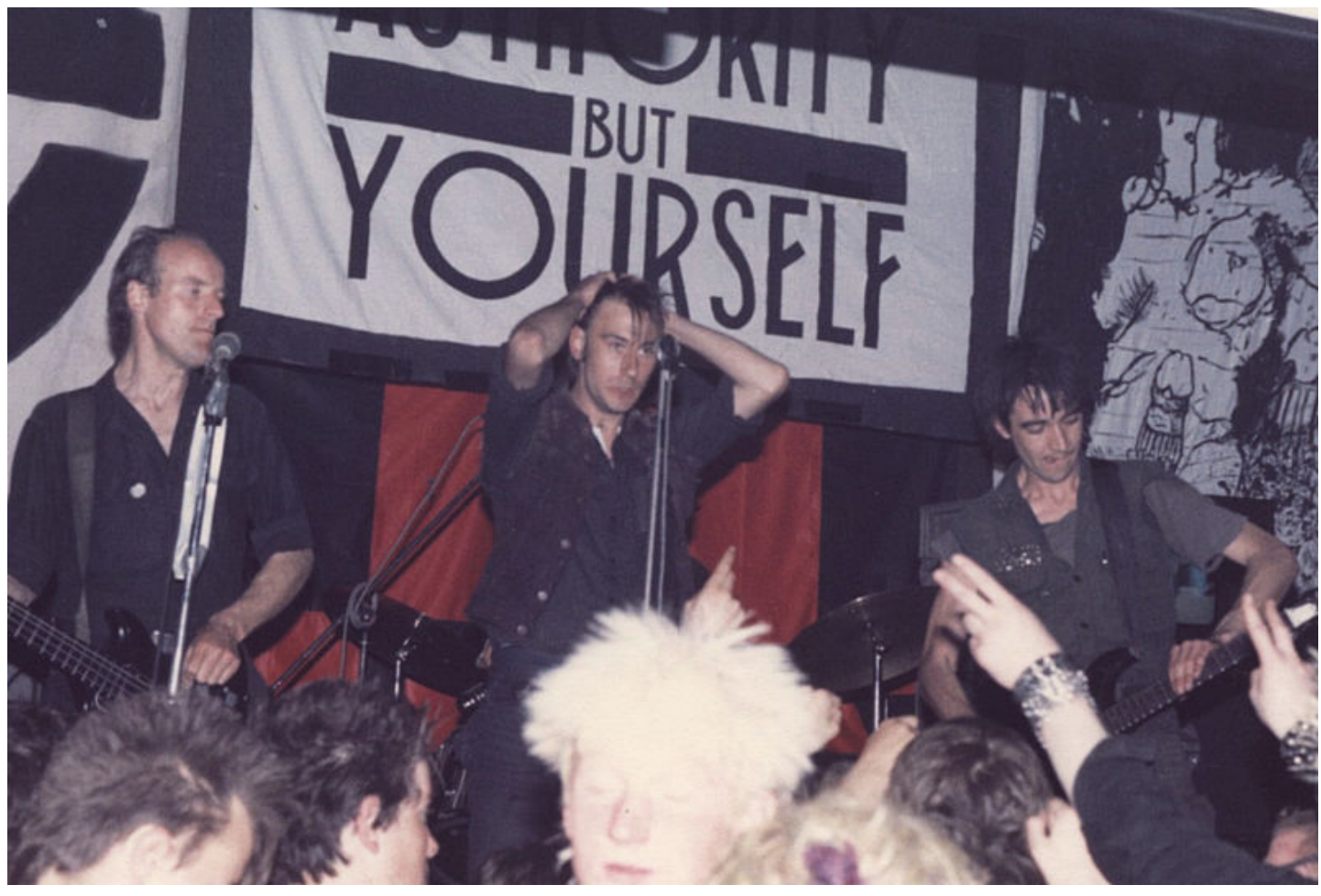

Crass performing live at the Cleatormoor Civic Hall, UK, 3 May 1984. Left to right: Pete Wright (bass), Steve Ignorant (vocals), N.A.Palmer (guitar). Photo by Trunt, via Wikipedia. Creative Commons Attribution.

In the literature on the genesis of British punk (from which anarcho-punk is routinely excluded) ${ }^{5}$ much attention has focused on the politics that informed the work of the Sex Pistols. ${ }^{6}$ In Lipstick Traces, Greil Marcus famously argued that the Anarchy in the UK rehearsed, in "crudely poetic form, a critique of modern society" that had earlier been articulated by the Situationist International, and the surrealist and dadaist movements before that. ${ }^{7}$ These radical phenomena, Marcus insisted, shared the principles of "negation, rebellion, destruction and detournement" in the collective efforts to overwhelm the social order they were confronted by. ${ }^{8}$ His contention has been dismissed by other authors, who see Marcus as attempting to ascribe a conscious political strategy to the Pistols' work where none existed, and to

\footnotetext{
${ }^{5}$ Much of the emergent historiography of anarcho-punk has been written by participants and alumni, including Penny Rimbaud, Shibboleth (Edinburgh: AK Press, 1998); Gee Vaucher, Crass Art and Other Pre Post-Modernist Monsters (Edinburgh: San Francisco: AK Press, 1999); George Berger, The Story of Crass (London: Omnibus, 2007); Ian Glasper, The Day the Country Died: A History of Anarcho-Punk 1980-1984 (London: Cherry Red, 2007).

${ }^{6}$ Academic attempts to explore questions of meaning in punk rock include Dave Laing, One Chord Wonders: Power and Meaning in Punk Rock (Milton Keynes: Open University Press, 1985); and Roger Sabin, ed., Punk Rock, So What? The Cultural Legacy of Punk (London: Routledge, 1999). One of the most widely cited academic works on the "subculture" of early punk remains Dick Hebdige, Subculture: The Meaning of Style (London: Routledge, 1979), a text which predates academic awareness of anarcho-punk.

${ }^{7}$ Greil Marcus, Lipstick Traces: A Secret History of the Twentieth Century (London: Secker \& Warburg, 1989): 18.

${ }^{8}$ G. Branwyn, "Lipstick Traces: A Secret History of the 20th Century, by Greil Marcus" [review]. Street Tech. http://www.streettech.com/bcp/BCPgraf/

Manifestos/LipstickTraces.html (accessed, 27 June 2010).
} 
mimicing Malcolm McLaren's own efforts to invent an "intentional" history of punk. ${ }^{9}$ In the case of Crass and anarcho-punk there has been little debate over the question of political intent, since the fact that politics served as the driving motive of the movement's founders has been accepted by both supporters and critics alike. ${ }^{10}$

Anarcho-punk emerged at the moment when so much of punk's original promise appeared to be disappearing, sliding into a quagmire of disappointment, self-destruction, and commercial corruption. The Clash drew deserved criticism for signing a contract with the major CBS label, but the band was distinguished more by its high profile than any peculiar lack of moral integrity. As a secondary wave of punk and new wave bands fought for mainstream attention, dozens of "punk rock" artists struck similar deals, many not even bothering to rationalize their actions or disguise their motivations. For all too many punks, both those in bands and those out in the audience, "smack" replaced amphetamine as the idiot's drug of choice, and the nihilism of "heroin chic" spread. New fashion rules came into force, as punk rock's own "designer labels" displaced the homemade creations of the amateur. As the market place responded to the dollar-potential of punk commodity, punk's anti-system resolve was tested and in many cases revealed as embarrassingly feeble.

As articulated by Crass, punk could still be remade into a force that recognized the movement's inherently subversive logic and which set out to change the world and redefine the lives of the movement's participants. So many of punk rock's initial reference points were urban-songs reflected from within on the boredom and alienation, as well as the excitement and thrill, of the city. It was an immediate distinction that Crass lived and wrote in a rural setting, eyeing "the city" warily from without. Crass were also distinguished by the factor of generation. Many members of the band were in their late-twenties or thirties. For many years, anarcho-punk effectively became the only one of the form's genres in which older performers were accepted as fully legitimate songwriters, performers and musicians. A third, and critical, distinguishing feature of the band was its perception of 1960s hippy counter-culture. When Malcolm McLaren, the Pistols' Svengali, had mischievously urged punks to "call all hippies boring old farts, and set light to them," he was reflecting a contempt for the cosy dope-addled indulgence of hippy, and asserting punk's claim to be its own Year Zero, severing connections to a pre-1976 past. ${ }^{11}$ By contrast, Crass-whose own criticisms of the failings of hippy the band's own critics wilfully ignored - saw many continuities between the aspirations of hippy and of punk, arguing that punk risked repeating hippy's own failure to subvert the status-quo.

In large part, the origins of anarcho-punk can be discerned in the creative and political work of a single commune of artists, performers, and activists. ${ }^{12}$ The band Crass was the latest in a series of projects initiated from the Dial House collective, based just north of London. Dial House had functioned as a magnet for performers, artists, organizers, and fellow travellers since the hippy era. The original incarnation of Crass was as a drums-and-vocal duo, until other house members were quickly absorbed and the band grew to full size. Although not all members of the band were musicians, several had worked on various theatrical and performance projects previously, including the avant-garde ensemble Exit. Although

\footnotetext{
${ }^{9}$ The debate is rehearsed in numerous autobiographical works including Glen Matlock, I Was A Teenage Sex Pistol (London: Virgin, 1990); and John Lydon, Rotten: No Irish, No Blacks, No Dogs (London: Hodder \& Stoughton, 1993); The debate is also one of the central themes of Julian Temple's celebrated film The Filth and the Fury (2000). The general debate about intent and authenticity in punk is raised in many of the general histories, including Alvin Gibbs, Destroy: The Definitive History of Punk (London: Britannia Press, 1996); Adrian Boot, and Chris Salewicz, Punk: The Illustrated History of a Music Revolution (London: Boxtree, 1996); and Nils Stevenson, Vacant: A Diary of the Punk Years 1976-1979 (London: Thames and Hudson, 1999).

${ }^{10}$ See, for example: George McKay, "Crass 621984 ANOK4U2," in Senseless Acts of Beauty - Cultures of Resistance Since the 1960s (London: Verso, 1996); and Richard Cross, “The Hippies Now Wear Black': Crass and the Anarcho-Punk Movement, 1977-1984,” Socialist History [UK], no. 26 (2004): 25-44; Brian Cogan, “'Do they Owe Us a Living? of Course they do!': Crass, Throbbing Gristle, and Anarchy and Radicalism in Early English Punk Rock.” Fournal for the Study of Radicalism 1, no. 2 (2007): 77-90.

${ }^{11}$ Macolm McLaren, quoted in Julian Temple (director). The Filth and the Fury, 2000.

${ }^{12}$ For reasons of space, the vital formative contribution of Poison Girls to anarcho-punk, who had been working independently along similar cultural-political lines to Crass, before the two bands began a period of close collaborative work, is not fully explored here.
} 
the band would not find public prominence until 1978-79, Crass were formed during the birth-pangs of British punk, taking to the stage of legendary London punk club The Roxy and playing numerous gigs, including several memorable outings at The White Lion pub in Putney with the UK Subs in the turbulent winter of 1977. It was not until the spring of 1978, and the release of Crass's first album The Feeding of the 5000 , that anarcho-punk broke through to find an audience of its own, and inspire the creation of an entirely new current, which would exist both inside and outside the punk milieu. ${ }^{13}$

Crass's approach to the business of punk rock music making was genuinely innovative. Their early recordings and live performances saw the band develop a signature sound that was unlike that of any other punk band (but which would itself be repeatedly revisited and revised during the course of the group's lifetime). Underpinned by the drive of militaristic snare-drum rhythms and prominent bass lines, were layers of overdriven guitar, and the impassioned vocals of a collection of different male and female singers. Crass's songs were short, intensive, aggressive and full-to-bursting with polemical agit-prop lyrics. Intertwined with the songs were sounds sampled from TV and radio recordings, feedback and soundloops, which were often used to bridge the transfer between songs and emphasize the totality of the recorded experience. Crass began from an assumption that the music was a delivery mechanism for the ideas which motivated the band and that anything in the panoply of rock-n-roll which threatened to compromise that intention had to be minimized or shunned (at least to the extent that the format would allow).

Anarcho-punk's message of a punk rekindled and reinvigorated, found an immediate resonance with a new audience-some already active inside punk, others cautiously observing from its periphery - and quickly Crass found themselves at the epicentre of a new and vital movement. That movement proved capable of establishing not only networks for recording, distribution, publishing and organizing, but also a distinctive and well-defined sub-culture, with its own recognizable moral and political ethos. Rallying around their call, Crass and the other bands claimed to take punk's anarchist imperative seriously-to identify their ambitions as "anarchy, peace and freedom" - and to reject mainstream punk's squalid nihilism as another act of political capitulation, an unacknowledged rehash of hippy's "drop-out, cop-out" politics.

Although Crass were reluctant to acknowledge the influence of particular schools of thought on their own writing, the band's critique of punk paralleled in many ways the less esoteric and abstract Situationist writing on the "co-option of subversion." Crass derided the key bands of the original first wave of punk for their fake acts of rebellion and sedition. Whilst pretending to denounce the musical and political establishment, such bands signed up to lucrative contracts with major record labels. They acquired managers and "representation" and began to replicate all the tired mannerisms and preoccupations of the older generation of bloated rock stars they had begun by denouncing. The rebels had been "incorporated," their acts of rebellion transformed into "spectacle"-the illusion of defiance, controlled by the system-their work transformed into the "commodities" of rebellion sold for profit in the market place.

Crass argued that such acts of betrayal were an affront to the individual creativity and dignity of the artists involved and also a catastrophic waste of punk's collective potential. Artists owed it to themselves, each other and to the wider movement to demand so much more. Crass's work helped to inspire the creation of a diverse network of bands, activists, publishers and organizers, committed in one way or another to the movement's creative and political priorities.

Like many other bands within anarcho-punk, the members of both Crass and Poison Girls adopted pseudonyms - such as Steve Ignorant, Eve Libertine (Crass), Vi Subversa, Lance d'Boyle (Poison Girls). While the idea of a "stage name" has been commonplace for artists since the birth of rock'n'roll, the often self-mocking names which anarcho-punk performers adopted to front their persona seemed intended to trivialize the idea of the celebrity of the individual musician. Visual representations of many bands (outside their appearances of live shows) were limited by a reluctance to publish any images of group members.

${ }^{13}$ Crass, The Feeding of the 5,000. Small Wonder Records, 1978. Weeny Two; subsequently re-released on Crass Records, subtitled The Second Sitting, 1981. 621984. 
Blurry, low-resolution photos of Crass had appeared on the inner-sleeve notes of The Feeding of the 5000 in 1978, but it was only with the release of the Best Before retrospective double-album in 1984 that one of the group's record sleeves featured individual photo portraits of all band members. ${ }^{14}$ Record releases by other bands on the Crass label between 1979-1984 also eschewed the use of photographs and what was seen as the "irrelevance" of a focus on individual appearance.

This refusal to adhere to the usual promotional rules of the entertainment business annoyed the mainstream music press. Eager to exploit the evident interest in the Crass amongst their readership, the 20 February 1982 edition of British music weekly Sounds included a full-colour double-page live photo of the band; the first time that such an image had been published anywhere. Appalled (if not at all surprised) by the effrontery, Crass decided to take no action against the paper's attempts to "expose" (and, in Crass's mind, to exploit and trivialise) them: "We knew nothing about it and we couldn't have stopped it," Crass told Tongue in Cheek fanzine. "[I]f we had known and had tried to have stopped it, Sounds would have advertised it as the 'picture Crass tried to ban', with people like that you can't win."

Crass fervently rejected the notion that theirs was an attempt to inject an alien political discourse into punk - insistent that all music, like all forms of art, was by definition political. The choice was not between embracing politics or rejecting it, but about which form of politics artists and movements adopted, and to which ends. During a rare television appearance on the BBC's new "youth show" Something Else, Penny Rimbaud insisted (over a playback of Money, Money, Money) that:

Abba is political in the sense that it supports the status quo attitudes. Every corner you turn [...] you can see confirmation of Abba's lyrics - because that is how everything is. ${ }^{16}$

Anarcho-punk's commitment to the principles of do-it-yourself (DIY) punk differed somewhat from the temporary enthusiasm of many in the movement's mainstream. All sides of the punk movement shared the problem that the music industry's hierarchy continued to control access to the means of distribution and circulation. The only option was to circumvent their control, and work independently of these agents. However, many punk bands seemed to see DIY work only as a "calling card"- as a means to get noticed by commercial interests and thus secure the contract that could end the reliance on "doing it yourself." Anarcho-punk worked from a different premise, one that sought to protect that autonomy, not offer it for sale to the highest bidder. Within anarcho-punk, DIY activity was seen as indivisible from the politicalcultural project by which the movement was enthused.

As Crass recorded, toured, and published, and the movement blossomed around them, its militants took up positions in the political movements of the hour, formed bands and self-published fanzines, set up venues and organized gigs, squatted buildings, sewed banners and dyed their clothes black. Crass served as the organizational catalyst for anarcho-punk recording, their house opened up to constant streams of visitors, and they serviced the fanzine network through the endless supply of interviews. Crass were central not only to providing an "unanswerable riposte" to the betrayals of punk, but to providing fierce and articulate opposition to the Falklands-Malvinas War; catalysing the squat rock movement (including arranging the mass Zig-Zag anarcho-festival squat in London in 1982, designed as an "inspiration to other people to open up more places" as venues, homes and action-centres),${ }^{17}$ and their numerous other stunts, hoaxes, and acts of mischief-making.

\footnotetext{
${ }^{14}$ Crass, Best Before. Crass Records, 1984. CATNO 5.

${ }^{15}$ Crass [interview]. Tongue in Cheek fanzine, No 2, n.d. but circa 1982.

${ }^{16}$ Penny Rimbaud (interview), Something Else. Manchester: BBC TV, 1981.

${ }^{17}$ See Crass, Squat Rock, Squat Rock [flyer], Crass, 1983; and Penny Rimbaud, Shibboleth: My Revolting Life (Edinburgh: AK Press, 1998), 244-245.
} 

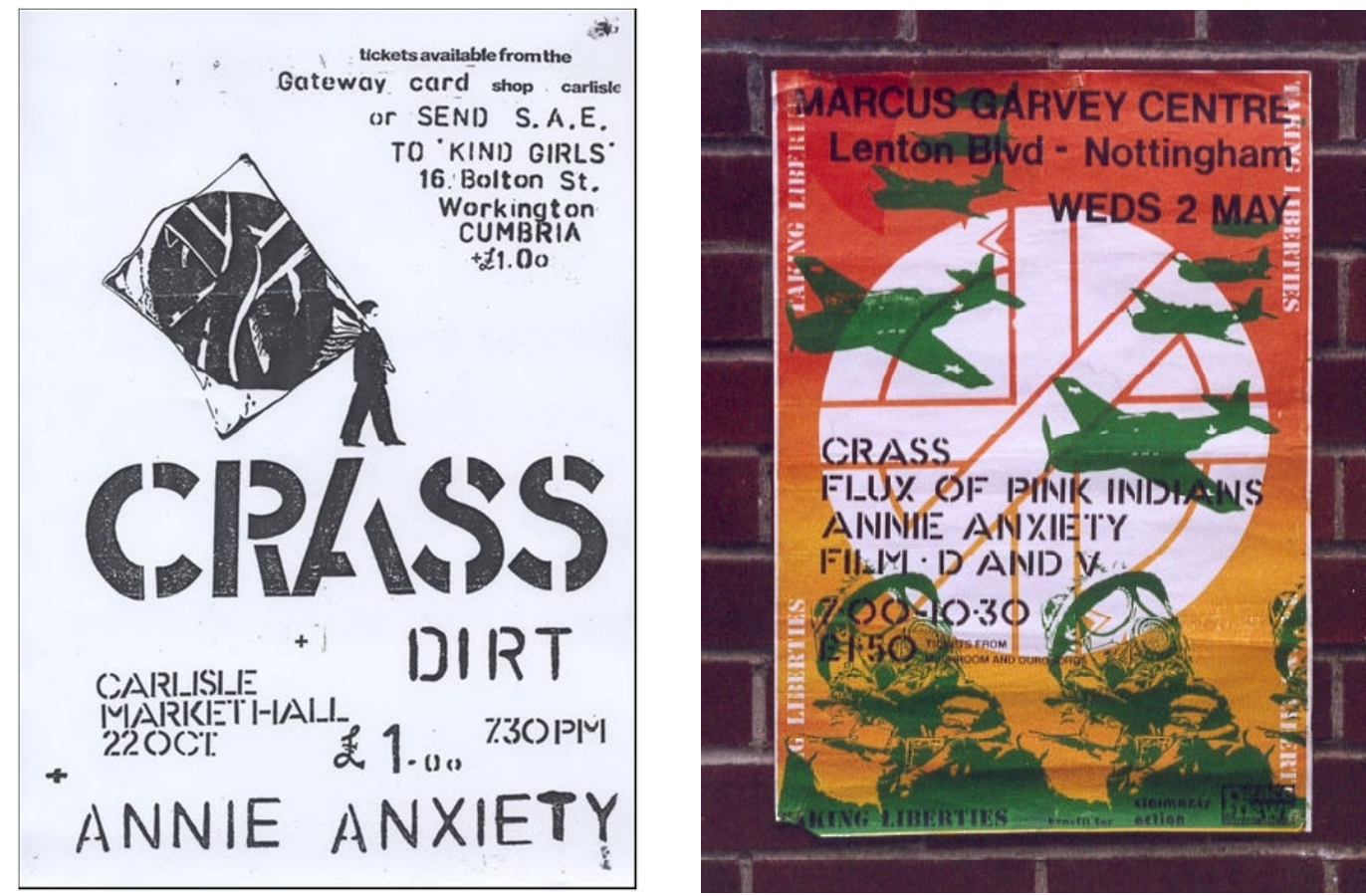

Left: Poster for Crass, Dirt and Annie Anxiety gig, Carlisle Market Hall. Right: Poster for Crass, Flux of Pink Indians, Annie Anxiety and D\&V gig, Nottingham Marcus Garvey Centre, May 1984.

The political and cultural work with which Crass were involved was informed by a fusion of traditions within anarchist thought, which sought to encourage those drawn to it to:

Demand our rights, refuse to be part of the authority which denies them and recognise that the system is nothing but a small handful of ruling elites who are powerless without our support. ${ }^{18}$

\section{"Anarchy and freedom is what I want"}

From its origins as a modern political discourse, anarchist thought has remained a complex matrix of traditions and ideologies - with one of the critical lines of division separating the individual from the social and collective traditions. ${ }^{19}$ Associated with theorists and thinkers including Errico Malatesta, Mikhail Bakunin, Emma Goldman and Alexander Berkman, the socialist anarchist tradition has always focused on questions of class relationships, entrenched political power and economic exploitation. ${ }^{20}$ Emerging from within this tradition were the anarcho-syndicalist, anarchist-communist, and anarcho-collectivist currents. Their shared goal has been to secure the liberation of humanity through the destruction of the capitalist

\footnotetext{
${ }^{18}$ Crass, A Series of Shock Slogans and Mindless Token Tantrums (London: Exitstencil Press, 1982), 61.

${ }^{19}$ See, for example: Ruth Kinna, Anarchism: A Beginner's Guide (Oxford: Oneworld Publications, 2005), 15-26; Colin Ward, Anarchism: A Very Short Introduction (Oxford: Oxford University Press, 2004). Marshall Shatz, The Essential Works of Anarchism (New York: Quadrangle Books, 1972); Irving Louis Horowitz, The Anarchists (New Brunswick, NJ: Aldine Transaction, 2005); John Hoffman, Citizenship Beyond the State (London: Sage, 2004).

${ }^{20}$ Errico Malatesta, Anarchy (London: Freedom Press, 1974); Mikhail Bakunin, God and the State (New York: Dover Publications, 1970); Emma Goldman, Living My Life (London: Penguin Classics, 2006). Alexander Berkman, The ABC of Anarchism (New York: Dover Publications, 2009).
} 
class system in all its guises (including in its "communist" disguises in the Soviet Union and eastern bloc states). The current of individualist anarchism has a more confused and contentious lineage, with the writings of Max Stirner serving a recurrent reference point, alongside the works of "libertarian economists" of various hues. ${ }^{21}$ Its concern to maximize the rights of the individual by limiting the intrusive power of the state, and by removing all obstacles to the "free actions of free individuals" has led it towards some contradictory alliances. ${ }^{22}$ If the contrast between these two anarchist schools is put in its most crude terms - that the collectivists seek to maximize social justice by minimizing exploitation; while the individualists seek to maximize individual liberty by minimizing state power - then the sharp difference in political strategies that each are confronted with becomes clear.

For the collectivist, the agents of social change must be those who suffer most directly under the system of exploitation: the working class and the economically oppressed. It is they who have the most immediate material interest in overthrowing the existing capitalist order, and they who are best placed to challenge the system of exploitation at its core. The task of anarchists is therefore to give practical effect to their solidarity with the most oppressed, and to urge the adoption of anarchist methods in the class struggle against exploitation. For the individualist anarchist, the agent of revolution is the individual. The task before them is to extend the frontiers of their own freedom and to make only those alliances which might assist that aim that do not restrict their own liberty in the process. ${ }^{23}$

Anarcho-punk's relation to the age-old divisions within the anarchist movement was skewed somewhat by Crass and anarcho-punk's effective separation from the "formal" British anarchist movement and tradition-represented by such publications as Freedom, Black Flag, and Anarchy, and by organizations including the Organisation of Revolutionary Anarchists and the Anarchist Workers Association-and by Crass's lack of concern with some of the key theoretical and historical questions around which the anarchist movement rallied. ${ }^{24}$

In many respects, the "new" and "traditional" anarchists maintained a wary, and often suspicious, mutual distance. Because the political pre-occupations of the punk anarchists were (by the standards of many traditionalists) "unorthodox" and at times "ideologically suspect," the renewed interest in anarchist ideas that anarcho-punk unquestionably stimulated was not universally welcomed by the stalwarts of the movement. Anarcho-punks showed interest in the Animal Liberation Front, squatting and the counterculture of the punk underground. To many in the ranks of the traditionalists, such concerns were at best secondary and at worst irrelevant. By similar token, anarcho-punks found the traditionalists' preoccupation with the ebb and flow of "wildcat" action by industrial and public sector workers, the intricacies of factional division amongst British Trotskyists, and debates over the shortcomings of anarchist strategy during the Spanish Civil War equally alienating. The separation was never absolute or unbridgeable, but the tensions remained unresolved.

The 1980 Bloody Revolutions / Persons Unknown single (a joint release by Crass and Poison Girls) made explicit the groups' political support for six defendants (several of whom were anarchists) then on remand and awaiting trial on what they insisted were bogus charges of "conspiracy to cause explosions." The record was also a fund-raiser for a putative new Anarchy Center in London, with receipts from the release subsequently underwriting the venue's start-up costs. The short life, troubled history and subsequent closure of the Center (which was always intended to be self-governing, and to cater to the interests of all sides of the movement) was something of a disappointment to all concerned. Crass later described the "unhappy liaison" which developed at the site "between the old school anarchists... and the anarchopunks." 25 Some of the Center's activists felt that, as a band, Crass should have been more closely involved in its running. Crass, on the other hand, were adamant that they expected others to take up the creative

\footnotetext{
${ }^{21}$ Max Stirner, The Ego and its Own (London: Rebel Press, 1993).

${ }^{22}$ Peter H. Marshall, Demanding the Impossible: A History of Anarchism (London: Fontana, 1993).

${ }^{23}$ This fairly rudimentary distinction, of course, only begins to address the complex of divisions, sub-stratifications and ideological crossing-over points within the anarchist tradition.

${ }^{24}$ For a succinct organisational history of the British anarchist movement in the 1970s, see Anarchist Federation, "In the

Tradition Part 4," Organise!, no.62 (2004).

${ }^{25}$ Crass, In Which Crass Voluntarily Blow Their Own (Crass, 1984).
} 
opportunities that their fund-raising made possible, and became concerned that the venue's potential had not been fully recognized by the collective responsible for its development. With no real agreement on the political causes behind the Center's premature demise, the experience did little to improve the prospect of future alliances between the punks and the traditionalists.

The pacifism of anarcho-punk (which began to corrode and fragment as the years passed) also reinforced the movement's isolation from a large part of the orthodox anarchist movement, for which political violence remained a requisite of revolutionary change. At the same time, Crass's own uncompromising anarchist principles made alliance with the staid and respectable British pacifist lobby equally problematic. It could easily be argued that the costs of these estrangements were small when compared against the benefits: both the traditional anarchist and pacifist movements remained politically peripheral; and both required forms of political practice which Crass, at least, would have found intolerable. Anarcho-punk's independence (initially) freed it of the weight of expectation and the burdens of tradition. This still left this movement of 'radical anti-militarists' with few organizational allies.

Although the "class politics" of anarcho-punk remained a conundrum (and a line of fracture the location of which eluded supporters and critics alike), Crass were intimately concerned with questions of political power and control, and the crushing alienation of impoverished lives endured under the iniquitous social and economic structures of "the system." It was clear that in denouncing that "system," Crass were attacking the cumulative oppressions of the family, church, state, police and courts and asserting the dignity, capability and creativity of "the people" in contrast. However, the precise political and economic nature of "the system" was not something upon which anarcho-punk dwelt in any detail. Instead there was a conviction that the pursuit of centralised power and wealth, protected by the threat and use of violence, distorted the lives of all those living under its sway, disfiguring personal relationship and maintaining a network of social relations based on exploitation. The task for the anarchist was therefore to extricate the Self as far as possible from the snares and entrapments set by the state, and to join the battle to overthrow "the system" through collective effort. Yet, such an approach might seem to suggest conflicting political priorities. On Bumhooler from Christ-The Album, Crass had railed against the peace movement's timidity in the face of the intensifying threat of nuclear war:

If they drop a bomb on us, we fucking deserve it.

We know we've got it coming, we fucking deserve it.

They've got a comfy set up, they'll try to preserve it.

We had the early warning, we can sit and observe it. ${ }^{26}$

$\operatorname{Big} A$, Little $A$ meanwhile urged the listener to realise the need to:

Be exactly who you want to be, do what you want to do. I am he and she is she, but you're the only you. [...] It's up to you to change your life, and my life's up to me. ${ }^{27}$

The implication of the first of these lyrics is that the ruling elite's of the world will plunge us into nuclear annihilation unless we collectively disarm them, and that abstention from that struggle is an untenable act of surrender. The clear message of the second is that the individual can effect meaningful change through the exercise of independent choice - that the constraints of the state can be undone through acts of conscious will.

At one level, the conflict might easily have been resolved, even if the protagonists rarely made the case-that the dichotomy was a false one; that the task was to pursue both avenues of change simultaneously; and that the efforts were mutually reinforcing, ${ }^{28}$ Crass suggested:

\footnotetext{
${ }^{26}$ Crass, "Bumhooler". Christ - The Album, Crass Records, 1982. BOLLOX 2U2.

${ }^{27}$ Crass, Big A, Little A. Crass Records, 1979 (the flipside of Nagasaki Nightmare single). 421984/5.

${ }^{28}$ See, for instance, George McKay, 'Crass 621984 ANOK4U2': 97-98.
} 
Anarchy is a personal choice, an act of commitment, a decision in your own head that to pursue a life that is ENTIRELY your own, free of restriction, free of fear, free of intimidation. OK, so you won't change the world tomorrow by becoming an anarchist today, but it's a start. Everything has to start somewhere, where better than in yourself? ${ }^{29}$

In practice things were to prove more complicated, with the tensions between individual liberty and collective effort proving frustratingly persistent. In the different spheres of anarcho-punk culture, pursuit of these two objectives continually struggled for pre-eminence.

\section{The attractions of anarcho-punk}

Anarcho-punk proved an irresistible attraction to the many young punks who found its message, and the medium of its delivery, compelling. From within the ranks of anarcho-punk's own "hardcore" emerged numerous musicians and artists, who formed bands and set up tape exchanges; and fanzine editors, who together produced hundreds of photo-statted and duplicated anarchist titles. These militants were the ones who joined demonstrations at the nuclear bases, and who swelled the number of hunt saboteurs, setting out to frustrate the animal-killing pleasures of the landed gentry. It was these activists who circulated the propaganda of the Peace Pledge Union, and the British Union for the Abolition of Vivisection; organized benefit concerts for numerous "good causes"; and took deadly seriously the logic of anarcho-punk's DIY imperative.

The dispersed and decentralized nature of so much of this activity meant that it was extremely difficult to quantify and assess. Outside of London, there were several towns and cities in the UK where the networks of anarcho-punk culture grew particularly strong: often centred around a local music "scene," prominent venues and resource centres or high-profile fanzines. Such focal points were found across the country-from Bristol in the south-west, to Sunderland in the north-east of England and Dunfermline in central Scotland. Some sense of the movement's geographical reach was provided by the Bullshit Detector compilation LPs compiled by Crass from the hundreds of band cassette tapes they were sent from bands and solo performers country-wide. ${ }^{30}$ The movement's collective worth only became fleetingly apparent at large scale demonstrations, where the "black bloc," with an anarcho-punk core, came together to march under its own banners. The bloc helped to provide the movement with a sense of cohesion and a form of identity, yet it gave rise to notion of uniformity, and gave credence to the concerns of some that what had emerged was a new exclusive all-or-nothing political subculture. In fact, the black bloc and the black-clad audience found at many anarcho-punk gigs, also served to disguise some of the important ways in which the movement was differentiated.

Even amongst the most politically-engaged anarcho-punks there were differences of emphasis and priority. For some, the demands of the peace and anti-nuclear movements remained pre-eminent, but for others the campaigns against vivisection and animal abuse had more urgent claim. Others active within the movement saw the promotion and generalization of anarcho-punk's own culture as the most pressing task-working to widen the network of bands, fanzines, and organizing centres, and convinced of the need to win over punks outside of the culture. Such anarcho-punks were less interested in joining marches and demonstrations than in setting up tape labels and fanzine distribution schemes, the better to spread the anarchist punk word. Most of these anarcho-punks saw themselves as "apart" from the punk mainstream, either ignoring it as a distraction or "intervening" in it to campaign for converts. Yet, not all of those involved with anarchist-punk saw the options in such exclusive either-or terms. While some anarchopunks disposed of their Clash LPs, along with their leather footwear as they severed their links with the punk "establishment," many others chose to retain their connections across the divide. It was a position attested to by the presence of "The Exploited" alongside "Flux of Pink Indians" and "Poison Girls" on the back of a thousand studded leather jackets, and was made less painfully contradictory through the work of

\footnotetext{
${ }^{29}$ Crass, It's Your Life, Live It [flyer], Crass, 1980 (circa).

${ }^{30}$ Three Bullshit Detector compilation albums were released on the Crass label between 1980 and 1984; showcasing the work of dozens of artists within the anarcho-punk orbit.
} 
bands as diverse as Discharge (whose stripped-down anti-war thrash-metal defined a sub-genre of its own) and Rubella Ballet (whose Day-Glo cartoon image illuminated catchy subversive pop anthems). Still others viewed the anarcho-punk exhortation to anarchist autonomy as a stimulus towards independence even from anarcho-punk "orthodoxy" itself; re-appropriating the movement's "ways of being" in other sub-cultural settings - ones that might dispense entirely with black clothing (in favour of more colourful hues of identity); extract only selective strands from amongst the movement's political creed; or reprioritise the balance between cultural work and political action, in favour of the production of music or art; or champion the work of performers defined more by their artistic extremism than by their political radicalism.

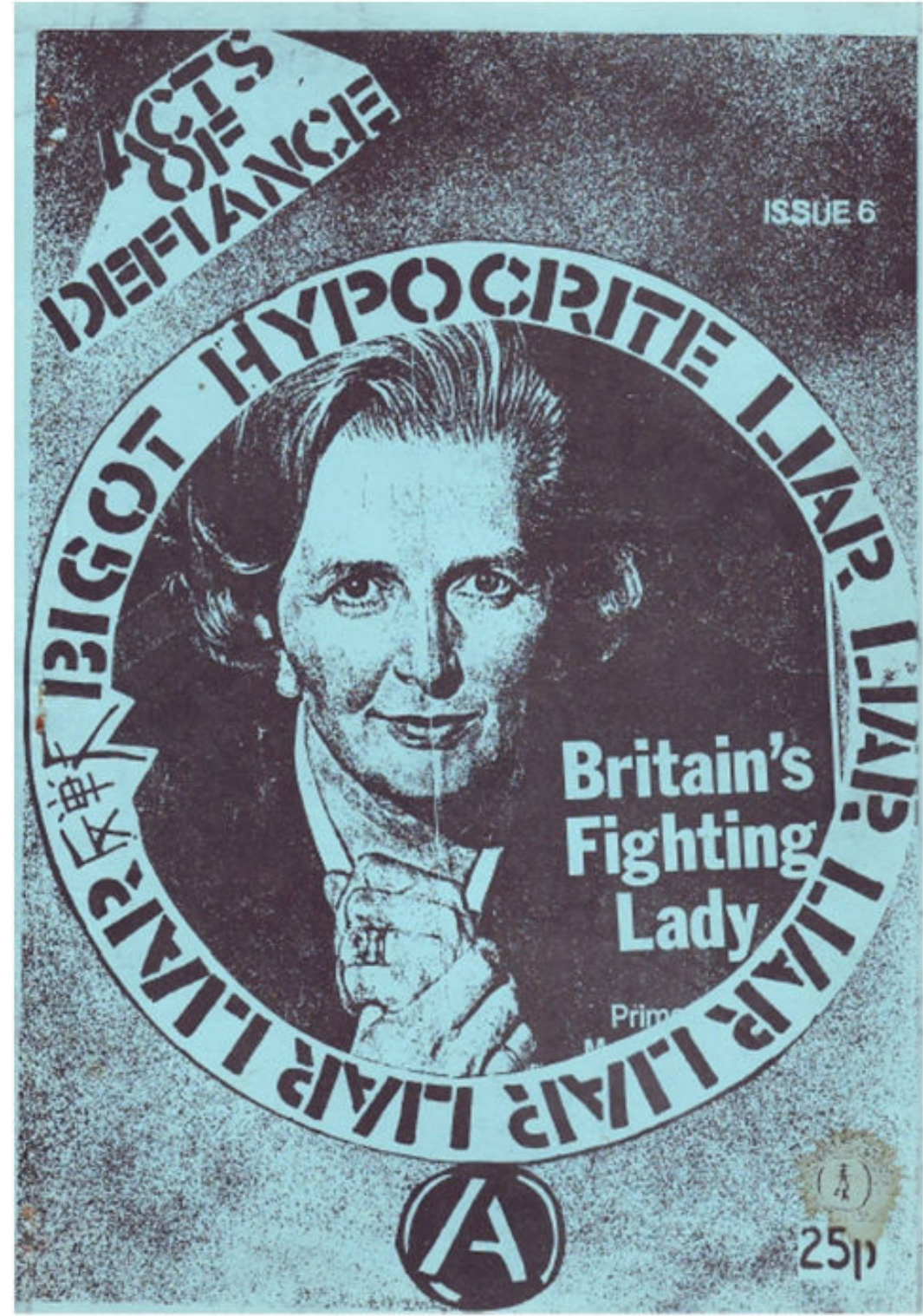

Front cover of Issue 6 of Acts of Defiance fanzine. 
But what-for the veracity of anarcho-punk itself-would prove to be one of the most significant ways in which the black-clad core adherents of the movement could be distinguished was over the question of identification and commitment. The movement critics-although few got past the primary target of Crass to take on the issue of the wider movement-seemed unable, from the outside, to see much of a distinction amongst "Crass punks." What perhaps served to keep such unevenness hidden was that the movement lacked a firm organizational shape, and fought shy of efforts to give the subculture's work a clear framework or form. This reluctance to marshal the movement's forces in collective acts (and in so doing test out its true significance) was a product of the fusion of a number of different political traditions, and a distinctive view of the question of political leadership.

\section{“Who's Your Leader? Which Is Your Flock?”}

Anarchist activists and propagandists of all types and in all eras struggle with the dilemmas that accompany an increase in the currency of their ideas: how to prevent the inspirational advocacy of selfactivity and collective self-reliance becoming its antithesis; how to stop the catalyst evolving (unintentionally) into a control mechanism that nullifies the creative efforts of others. In conflict with everything that they had worked for, Crass came to feel that the group was being forced into a leadership position within the anarcho-punk movement. Gee Vaucher suggests that, despite the band's efforts:

Crass became "the word" [...] Everyone waiting for the next direction, and that's not what we wanted. ${ }^{31}$

If this were true, it would appear to be a straightforward negation of the defining ethos of anarcho-punk. The intention had always been to inspire the self-activity of others and to urge them to discard the dead weight of ideologues and to work free of institutional entanglements. In 'Where Next Columbus?' from Penis Envy, lyricist (and vocalist) Eve Libertine had mocked the idea that fulfilment was to be found in accepting a subservient position amidst a docile crowd of fellow believers. One section recounted, dismissively: "Marx had an idea from the confusion of his head, then there were a thousand more waiting to be led. .." 32

In some respects, it was not surprising that Crass felt that others were trying to manoeuvre them into a "leading position" within the anarcho-punk movement. Crass had certainly been one of the key catalysts for the subculture, and this pre-eminence was reinforced by the distinctions of age, experience, and literary and political acumen that defined their work. Relatively few of the eighteen and nineteen year olds drawn to anarcho-punk could easily match the political sophistication or poetic maturity of Crass's more cerebral work, and it was understandable that many of these newly energized young activists might look to the band "for a lead." Crass's determination to pour the receipts from their record releases back into the work of their label also meant that the band provided the subsidy and sponsorship for the creative and recording work of many other artists-something which inevitably pushed the band toward the epicentre of the movement's profile. Flux of Pink Indians, Conflict, The Subhumans, and other artists later established labels of their own, but Crass Record's centrality to the movement's musical output remained.

Crass's enthusiasm for the principles of DIY committed the band to dauntingly high workloads. Up until the release of Stations of the Crass in 1979, the band took as much direct responsibility for the production of their records as possible-folding the sleeves and glueing-in silk-screened anti-war patches by hand. As demands for the band's records increased sharply, this quickly became impractical and the work had to be farmed out. But as Crass did their "best to stop getting lost in the size of what is happening to us" the collective still retained complete responsibility for arranging tours, authoring, and printing all of the band's written material, preparing banners and other artwork, editing film and video presentations, liasing with other supporting others bands - and personally answering the many hundreds of letters which

\footnotetext{
${ }^{31}$ Gee Vaucher, quoted in Perry, Neil and Hugh Fielder, “Crass: A Militant Tendency?” Sounds, 25 October, 1986.

${ }^{32}$ Crass, “Where Next Columbus?” Penis Envy, Crass Records, 1981. 321984/1.
} 
poured in to Crass's PO Box from around the world each week. ${ }^{33}$ So determined were Crass not to separate themselves from those interested in their work, that their commune played host to relentless waves of punk visitors all year round-who were put up in the house or camped out in the garden. This conviction on the need to remain open and accessible to "fans" inevitably increased the pressure on the members of Crass, who were constantly "under scrutiny" and being made to justify themselves and their work in the one place which might otherwise offer some personal respite. Crass's desire to maintain direct control over every aspect of their own work; the fact that their imprint was so visible on so much anarchopunk material. Also, the very accessibility of Dial House, all meant that some (though not all) in the movement came to expect that organizational and political direction would inevitably come from them. Although Crass were far from alone in the movement in enduring physical attacks on their performance by fascist gangs, or blatant state surveillance of their work, the band did bear the additional brunt of repeated legal prosecutions and police raids and the press scrutiny that accompanied this heightened level of harassment. Such a position in the public spotlight further reinforced the band's pre-eminent "notoriety."

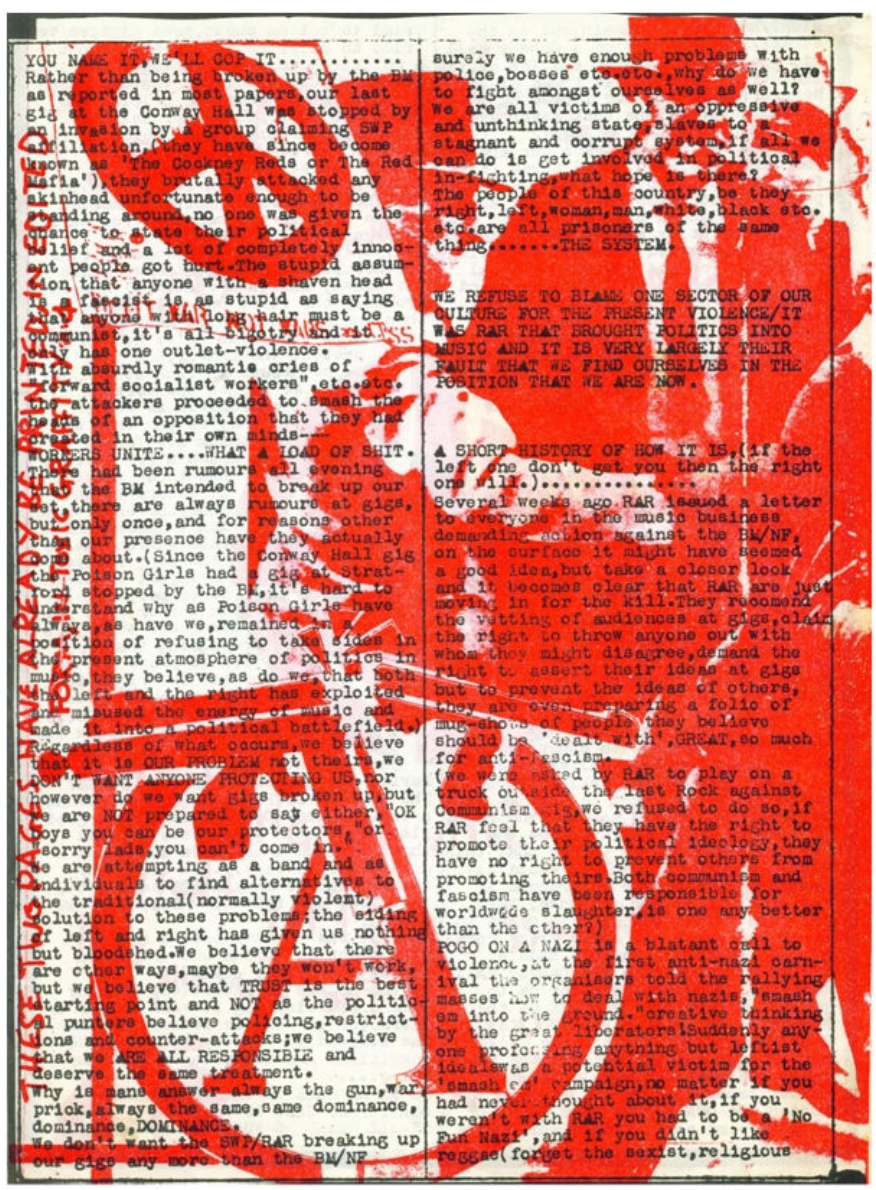

Page detail from a Crass and Poison Girls feature in Kill Your Pet Puppy fanzine.

\footnotetext{
${ }^{33}$ Quotation from a Crass news-sheet, mailed out with correspondence, not dated, but 1981. PO boxes are a mailbox service provided by the Post Office in the UK. Crass continued to rely the "anonymity" provided by having PO Box 279, London N22 as their public contact address even though knowledge of the band's actual Dial House residence became increasingly widespread amongst movement activists.
} 
The close scrutiny of Crass was offset, at least in part, by very scale and diversity of the movement which evolved from early 1979. The existence of a multitude of other bands and agencies; the vitality of those localized anarcho-punk scenes outside of London; and - most fundamentally of all - by the determination of many of those active within anarcho-punk to try to make good on its principles by putting them into practice. That fierce sense of autonomy and self-reliance provided the strongest defence possible against any tendency for the movement to defer to the wishes of its most prominent members.

Crass were far from alone as a source inspiration and guidance within anarcho-punk. Other bands occupied positions of significant influence - both Flux and Conflict took a far more prominent position over the questions of animal rights and animal liberation. While Crass supported their efforts, and made occasion forays into the territory, in propaganda terms it was political ground they were willing to cede to others. While some saw Crass as overly concerned with the position of the individual, others within the anarcho-punk orbit took a greater interest in issues of relationships, intimacy and the distorting efforts of gender expectations and family roles. Poison Girls in particular, with whom Crass toured extensively between 1979-1981, before the two bands opted to work independently again, addressed these issues directly, and were able to connect with a different yet overlapping audience. Other bands quickly found the anarcho-punk model too restrictive creatively, and opted for alternative ways of working. Chumbawamba, in particular, chose a different pop and theatrical sensibility for their performances. As the movement grew in size and confidence, its diversity increased, as did the willingness of many of its most engaged political activists to begin to make choices and selections of their own-much of this change came about at the time of the 1984-85 Miners' Strike (a watershed in British politics in the 1980s). ${ }^{34}$ Many chose to question some of the key assumptions which had guided their work over the previous five years, and looked elsewhere for political engagement.

It was, however, a growing sense of frustration (with the state of the world around them; with the impact that their own creative efforts were making; and with the nature of Crass itself) which led the band to record and issue the intentionally controversial album Yes Sir, I Will - which would dispense with most of the familiar rock elements of the band's work to produce an extended performance piece which delivered a fractured, discordant and jagged soundscape to accompany the delivery of a single polemical essay. Crass would later described the release as: "an impassioned scream directed towards the wielders of power and those who passively accept them as an authority. ${ }^{35}$ While many of those interested in (or at least intrigued by) Crass's work might have lauded the ambition, the recording itself was immediately contentious.

Berger argues that: "The concept of a collection of songs had been abandoned in favour of one lengthy monologue over a background that could best be described as a racket, improvised noise that slams the door shut on any attempt at communication." ${ }^{36}$ Glasper suggests that while the recording represented Crass's "most articulate and lasting statement lyrically," the soundtrack "was an awful noise that tried the patience of even the most ardent Crass fan." ${ }^{\text {I }}$ In contrast, reviewing the album at the time of its release, the campaigning anti-militarist magazine Peace News insisted: "There is not enough room to praise this record enough ... except to say that it is aimed at people like you-people who care." ${ }^{38}$ The sense that the record was intended to motivate Crass's politically engaged core to greater efforts, and to challenge those focusing "too much" on the music, fits with Rimbaud's own retrospective view. The record was designed to polarize opinion, by jettisoning the remaining rock'n'roll reference points with which the audience was familiar, and with which Crass had become frustrated. "[W] did a piece of music that wouldn't allow people to have any fun to it," Rimbaud recalls. "We thought we would wipe the floor with people-that they would walk out of our gig and have to face what was happening . . but they didn't. They jumped up

\footnotetext{
${ }^{34}$ See a discussion of the shifting centres of gravity within the British anarchist movement at that time in Benjamin Franks, "British Anarchisms and the Miners' Strike," Capital and Class, 87. (2005): 227-254.

${ }^{35}$ Crass, In Which Crass Voluntarily Blow Their Own (Crass, 1984).

${ }^{36}$ Berger, The Story of Crass, 243.

${ }^{37}$ Glasper, The Day the Country Died, 26.

${ }^{38}$ Su B. Versia, "Yes Sir, I Will” [review], Peace News, 2 March, 1984.
} 
and down, made the most they could out of a bad job [...] Anything but start thinking. ..." The failure of Yes Sir, I Will to transform the perception that the anarcho-punk movement had of itself: "can be seen as heralding the start of the movement's own endgame."39

While Crass fought against being forced into a leadership role, they also rejected any approaches that asked them to endorse new anarchist-punk organizations. In some cases, such as the time that a group of young punks asked for "permission" to set up a "Crass Barmy Army," the negative response they received was immediately understandable to most of activists. But Crass had a wider political reluctance for the movement to set up institutions of its own, convinced that the most effective political actions were those which adopted spontaneous, ad-hoc and temporary forms. Part of Crass's attack on the political practice of the authoritarian left focused on its obsession with organization and bureaucracy, and its pursuit of recruits who were signed-up simply to service the alienated needs of the party and its leaders. Crass railed against the deadening influence of all institutions which sapped individual will. In Yes Sir, I Will, Crass expressed the concern that anarcho punk itself risked becoming "another institution, another cross to bear."

In part, Crass sought to displace the organizational responsibility to other-often less radicalorganizations in the peace, disarmament, and civil liberties lobbies, providing contact details on record sleeves and in flyers. The organizations listed were rarely "recruiting bodies" but rather sources for information and support. There were few indications that Crass had "prepared the ground" for the kinds of contacts that these organizations were likely to attract through anarcho-punk's efforts, and even less evidence that these campaign groups were keen to reciprocate for the attention it won them. Although it reflected an openness and generosity of spirit for which Crass were rarely given credit, it further emphasized how far the individual was being urged to construct a political agenda of their own.

It was significant that the background of many of the founder members of Crass lay in the counterculture and alternative movements of the 1960s and early 1970s rather than in the "straight" political organizations of the radical or libertarian left. It is indicative that when the band was ready to launch one of the earliest political campaigns "as Crass"-a concerted stencil graffiti campaign on London Underground (pictured on the fold-out front cover of Stations) - they took the initiative themselves, without reference to other potentially supportive groups, seeing such independent action as the most relevant and least constricting political model. Crass, meanwhile, resisted the attempts of others seeking to recruit and incorporate them-side-stepping the varied attentions of those claiming to be from the Baader Meinhof gang, and those pretending not to be representatives of the Russian Embassy. ${ }^{40}$ Crass continued to wrestle with the contradictions of urging individual and collective action while still declining to take responsibility for its organization. All radical, fringe groups, especially those held together only by the effects of a shared sub-culture and an informal network of connections and contact points, struggle with the issue of political mobilization. For anarcho-punk, additional pressure came from the fact that the movement's allies outside its own milieu were few in number, and that the culture's absolutist political ambitions and immediate day-to-day practice both tended to neglect the complex question of strategy-of clarifying how the movement's goals might ultimately be realized; and of articulating how the methods and messages of anarcho-punk would contribute to, underwrite and help to shape this evolving revolutionary program.

Ironically, the fight for individual liberty appeared to impose some significant personal constraints on some of its more vociferous activists. Rimbaud suggests that significant costs accrued to Crass's determination to merge their individual identities in the shared public projection of the band. By 1982, Rimbaud observes: "For five years our lives had been dominated by the voracious appetite of 'Crass the Organisation'." 41 Two years later he suggested the implications of those demands for the members of Crass had become even clearer: "We'd shared seven years of our lives together, but now we were individually acknowledging that we had sacrificed our own needs and desires in the process." ${ }^{\$ 2}$

\footnotetext{
${ }^{39}$ Rich Cross, "Love Songs" [review], Freedom, 26 June, 2004.

${ }^{40}$ Penny Rimbaud, Shibboleth, 259.

${ }^{41}$ Ibid., 240.

42 Ibid., 277.
} 
On only one occasion did Crass organize a political initiative entirely of their own-a planned "walking tour" of some of the key installations of the nuclear state, which was to begin at the Windscale nuclear power plant in northern England, before wending its way south to take in nuclear bases and other sites of "interest." The intention was to bring together and rally the ranks of the anarcho-punk movement, and test out its political muscle-giving the movement a clear focus beyond the gigs and fanzine networks. Mailouts from Crass urged fans to "get your walking shoes warmed up," ${ }^{43}$ but before the details of the tour could be finalized, Crass thought again and cancelled the event. Worried by the likely outcome of a series of confrontations between anarchist punks and police and MoD units tutored in the "militancy" of the "black-clad mob," they pulled the plug. Criticism abounded at this change of heart (with some critics deriding Crass's apparent loss of nerve) but the band never again broached a similar plan. It suggested a growing sense of uncertainty about the next direction in which the movement could evolve.

The series of anti-capitalist Stop the City demonstrations, held in the financial center of London between 1983-84, offered the clearest indication of the anarcho-movement's capabilities and limitations. Although not initiated directly by Crass, anarcho-punk bands and fanzines quickly made the demonstrations a centerpiece of their propaganda work, and punks comprised a clear majority of the participants at the demonstrations themselves. ${ }^{44}$ The "demands" of the demonstration reflected classic "impossiblist" anarchist sentiment-that the City should cease its exploitative, world-plundering, warfinancing work, and disintegrate along with the capitalist system that it serviced. What distinguished the demonstrations was not their size or their political sophistication, but their non-traditional nature-the lack of a formal structure, the diversity of the political issues being promoted, the absence of dignitary speakers or party paper-sellers-and its reliance on the creative activity of the participants to secure its effectiveness. Many of the tactics employed focus on disrupting 'business as usual' and to snarling up the operation of the City itself through occupations of corporate space and the streets around them. Crass declared the first demonstration, on September 29, 1983, as "a massive success, the best gig of the year." 45 It was an illuminating metaphor, encouraging punks to think of political mobilizations and live music shows as indivisible events. By this measure, inspiring anarcho-punk "gigs" did not require the involvement of music at all.

Stop the City certainly marked out a new political terrain for anarcho-punk, aiding the generalization of its politics beyond a pre-occupation with The Bomb. The reliance on decentralized, leaderless "affinity-group" based action also suggested how the movement's strategies might develop in the future. At the same time, STC showed how challenging it would be to extend such "self-activity" exponentially. At the London demonstrations, and ones that followed in Leeds and elsewhere, only a minority of participants took up that challenge and came prepared. For many, the notion that the success of the demonstration rested on their initiative rather than simply their presence was lost:

That passivity threatened to drag STC back into the rut and routine of just another demo. The sense of collectivity and togetherness, of carnival and defiant celebration - one of the defining themes of the day - was reached only fleetingly. ${ }^{46}$

This highlighted a number of critical problems with the way the movement functioned politically. There were without doubt, as critics derided, 'Crass punks' who saw the band as the final arbiter of all political questions, and the source of ideological rectitude. For them the words of Crass were to be accepted as literal certainties, with:

Some "fans" being dogmatic about Crass, revelling in the austerity and viewing every line as an irrefutable truth. ${ }^{47}$

\footnotetext{
${ }^{43}$ Crass news-sheet, not dated, but circa early 1983.

${ }^{44}$ See a description of events in Rimbaud, Shibboleth, 245-246.

${ }^{45}$ Penny Rimbaud, "Stop the City," Punk Lives, no. 10 (1983).

${ }^{46}$ From a talk on "Stop the City" given by the author to the Riotous Assembly group in Manchester, 2 June, 1999.
} 


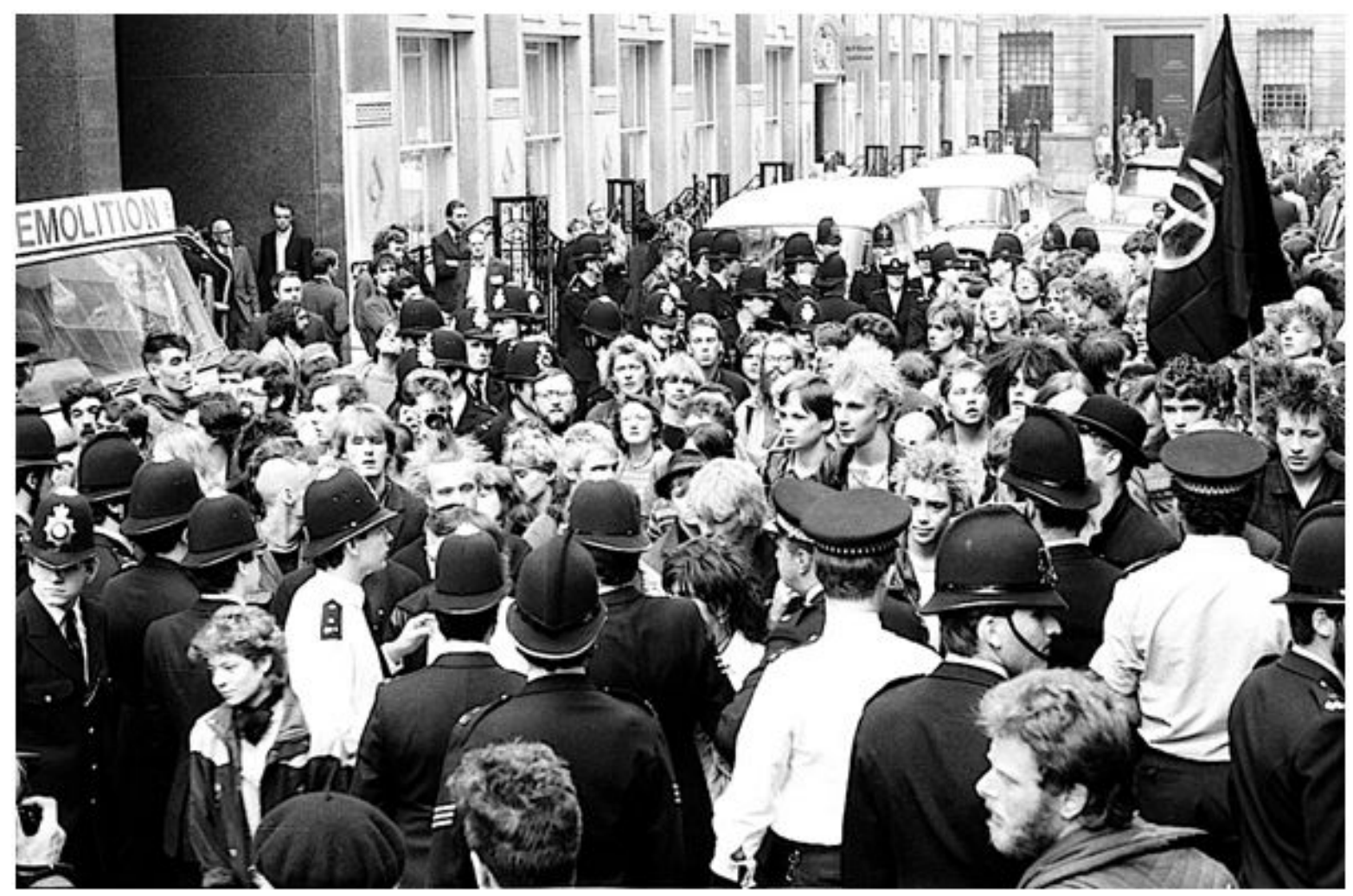

London Stop the City demonstration, 1983. Photo by: camera_obscura [busy], via Flickr. Creative Commons Attribution.

What such behaviour missed entirely was the band's hope to inspire critical self-reflexivity and independence of thought. At its weakest, much of the fanzine, lyrical and musical work undertaken by activists and artists in the anarcho-punk orbit replicated, rather than enhanced or extended, Crass's own. Some fanzines "reproduced" the iconography and polemic of Crass, and a predictable uniform style began to circulate and be recycled. Some of this work appeared superficial and perfunctory. Repetition and overfamiliarity began to diminish its impact. Some fans appeared to seek shelter in the collectivity of anarchopunk, rather than seeing the subculture as the context for active political work. They retained a belief that buying the records and attending the gigs was the political act that anarcho-punk demanded. For others it represented a determination to slip inside the "black-bloc" and to shun difference and distinction in the desire to demonstrate their strength of affinity with the movement, and their identity as anarcho-punks. And while Crass (away from their live performances) refused to relinquish their sense of playfulness, or their enthusiasm for acts of satire and subversive pranks - many fans seemed determined to languish only in the darkness of shrill denunciations of war, animal suffering and impending Armageddon.

\footnotetext{
${ }^{47}$ Mark Hodkinson, "Foreword," in Love Songs, Crass, xvi (Hebden Bridge: Pomona, 2004).
} 


\section{"Increase the pressure"-the solidarity and strains of anarcho-punk}

The force of anarcho-punk's shared subcultural values brought with it both benefits and costs. In what was, for all anti-capitalist currents, the deeply antagonistic political atmosphere of early-1980s Britain it offered its supporters reassurance, encouragement, support, and respite. There's also little doubt that the thought of the vitriol that would have showered down on any anarcho-band capitulating to a major label helped to keep some waverers in the movement on the straight and narrow. The operation of such social pressure might seem an entirely reasonable example of collective anarchist self-discipline in action, but Crass felt the same pressures more acutely than most, as Rimbaud reflected in 1986:

People have been waiting years for us to "sell out." We didn't have a holiday for eight years because were worried that someone might fuckin' see us getting on the boat, and I'm serious. It wrecked us. ${ }^{48}$

More problematic was the sometimes restrictive cultural environment which anarcho-punk generated, in which shared anti-militarist and vegan-vegetarian ethics, combined with an all-black-cotton dress code, could produce a new conformity and narrowness of its own-one from which participants strayed at their peril. If anarcho-punk's judgemental reflexes reinforced its "exclusiveness," the strong culture of tolerance inside the movement produced other unintended consequences. So strong was the enthusiasm to draw in fanzines and bands who took the anarcho message to heart, that there was little collective scrutiny of the substance of their convictions. It was not difficult for editors or song writers to work though a superficial "check-list" of political issues, to produce an identikit and unreflective anarchoplatform, divorced from any engagement with the real political world, and entirely unconcerned by the subculture's estrangement from so much of it. As Crass, at the height of their frustration with the movement's self-satisfaction, commented:

Anarchy, freedom, more games to play?

Fight war, not wars? Well it's something to say

Slogans and badges worn without thought, instant identities so cheaply bought. ${ }^{49}$

The repulsive imagery of the battlefield and the slaughterhouse also encouraged some artists to wallow in the horror of the degradation and suffering they presented to their audiences. For a few on the fringes of anarcho-punk this teetered on the edge of a deeply alienated practice, in which the mutilation and misery on show ceased to be the means to inspire a political response but became instead a dependable source of shock-art. Some fans appeared equally content with the parental outrage that the raw power of anarchopunk's musical invective seemed to guarantee. In neither case was the anarcho-punk movement effective in defining what the minimum standards for recognition and inclusion might be. It was ironic that a movement so often criticized for its "intolerance" should in practice accept as legitimate the participation of any band, fanzine or organizer willing to make public their commitment to "the cause."

But for all its shortcomings, anarcho-punk offered opportunities to those inspired by its clarion cry to which no other manifestation of punk could come close. Certainly, some individuals were reluctant to treat anarcho-punk as more than a short-lived distraction, while others sought cover in the black-clad uniformity its ranks seemed to offer. There were those who absorbed every pronouncement by Crass as a self-evident truth; and those who flailed around in the mosh-pit unaware that they had missed the message entirely.

\footnotetext{
${ }^{48}$ Quoted in Neil Perry and Hugh Fielder, "Crass: A Militant Tendency."

${ }^{49}$ Crass, "You Can Be Who?" Christ - The Album, Crass Records, 1982. BOLLOX 2U2.
} 


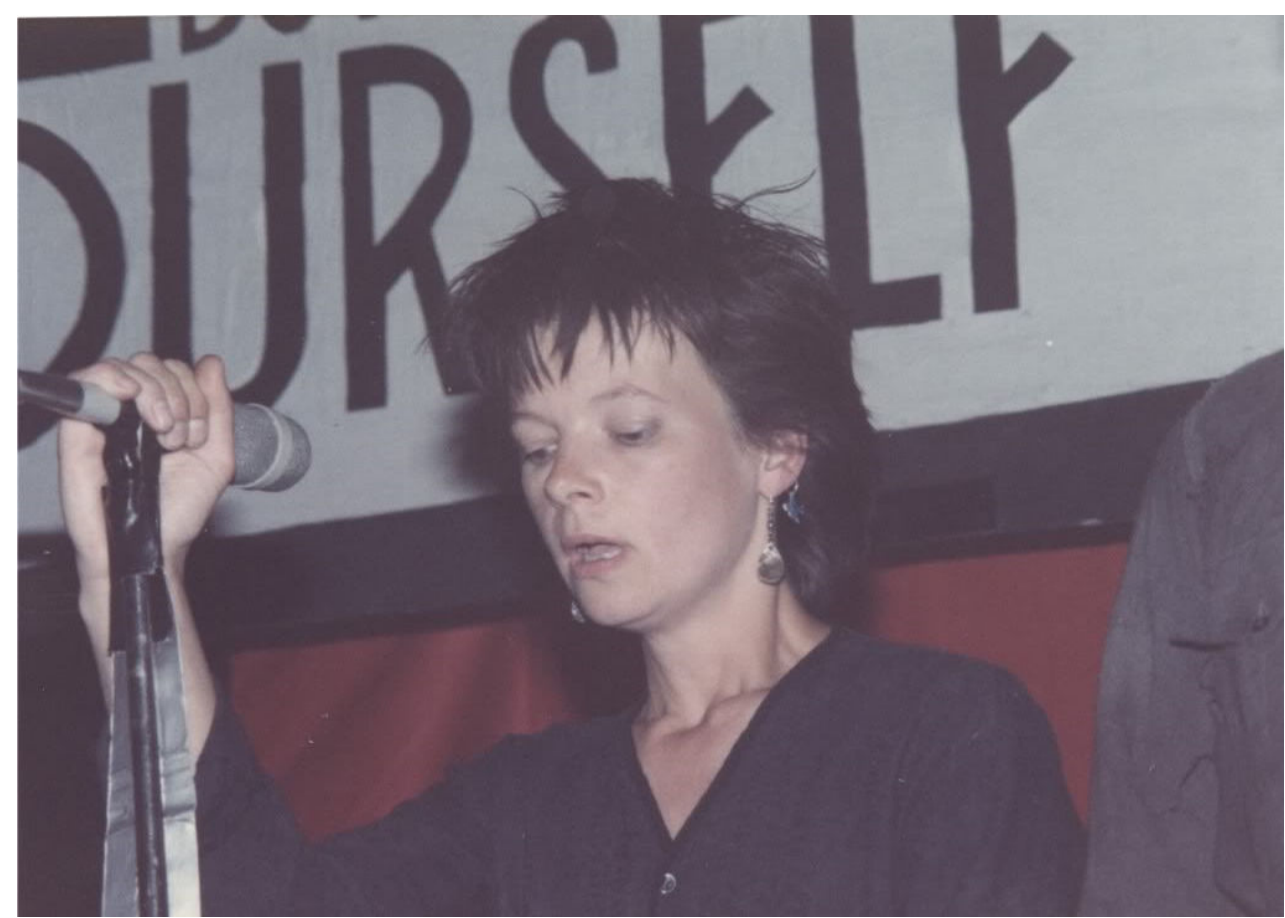

Eve Libertine of Crass performing live at the Cleatormoor Civic Hall, UK, 3 May 1984. Photo by Trunt, via Wikipedia. Creative Commons Attribution.

If only a proportion of those energized by Crass's example truly explored the possibilities that the reclamation of punk offered, these explorations still led to some startling creative cultural and political acts. And much more significant than the inevitable petty rivalries and squabbles which sometimes strained the unity of the movement was the palpable sense of affinity and camaraderie which so many bands, fanzines and collectives who identified themselves as "anarcho-punk" came to recognize as normal. Organizing together, there was an assumption that work and production was never-for-profit; that effort would be reciprocated; costs and burdens shared. Ever fallible, the results of such human collaboration were always going to be imperfect, but it remains remarkable how capable and resourceful anarcho-punk's network of activists recognized themselves to be. Managers, promoters, aspiring bureaucrats and party-politicians were considered as an alien species in a do-it-yourself culture which prized self-activity and denounced abstention. In a punk milieu crowded with would-be impresarios, rip-off merchants and false prophets, it remained effectively uncontaminated by corporate interests.

Anarcho-punk might never have fully resolved the tension between its preoccupation with individual choice and its desire to make the world anew, yet its battles on both fronts were informed by the implicit recognition that "the revolution" would require self-aware and self-directed individuals who understood that the destruction of the economic, political and military status quo could only be attained through the collective action of the dispossessed and exploited. It was far from obvious that the anarchopunk movement appreciated that the realization of individual liberty and collective freedom required the building of inclusive alliances far beyond the confines of punk's own prickly dissident community. What was not in doubt was the movement's fiercely independent radical spirit, its firm belief in the importance of conscious human agency, and its assertion of the individual's responsibility to reject the State's authority in favour of their own. 


\begin{abstract}
The heartfelt conclusion to the fifth studio album by seminal British anarchist punk band Crass urges the listener to take up the challenge of personal freedom and responsibility. The exhaustion of vocalist Eve Libertine's delivery serves to emphasis both the sincerity and desperation of the message. Taken in isolation, such a stark declaration of the "primacy of the individual" might suggest that the concern of anarchist punk began and ended with the agency of the single person. And yet, there can be little doubt that from its 1977 origins onwards, the self-declared role of anarcho-punk was to act as the catalyst for radical, collectivist opposition to the War State. Was there an unresolved tension between anarcho-punk's concern to maximize the "rights of the individual," free from societal interference, and its demand for mass mobilization against State power? Did this reveal a critical fault line in the movement's anarchist manifesto? How could anarcho-punk's celebration of individual liberty be reconciled with the movement's "counter-cultural conformity," as suggested by the critics? This article explores the relationship between the individual and the collective in the culture, politics, and practice of the British anarcho-punk movement, between 1977 and 1984.
\end{abstract}

